\title{
ВИХОВНЕ ТА ПЕДАГОГІЧНЕ ЗНАЧЕННЯ ЩОРІЧНИХ ВНУТРІШНЬОВУЗІВСЬКИХ НАВЧАЛЬНО-МЕТОДИЧНИХ КОНФЕРЕНЦЙ
}

\author{
В. К. Івченко, В. В. Сімрок \\ Державний заклад “Луганський державний медичний університет”
}

\section{EDUCATIONAL AND PEDAGOGICAL SIGNIFICANCE OF ANNUAL IN- ESTABLISHMENT PRACTICAL AND METHODICAL CONFERENCES}

\author{
V.K. Ivchenko, V.V.Simrok \\ State Establishment "Luhansk State Medical University"
}

\begin{abstract}
У статті висвітлено досвід державного закладу “Луганський державний медичний університет” з проведення щорічних навчально-педагогічних конференцій. Зроблено висновок, що проведення таких конференцій являс собою систему набуття педагогічної майстерності з різних питань медичної освіти всіма викладачами університету, с елементом педагогічної технології, що дозволяє підвищити педагогічну майстерність не тільки молодих викладачів, які ще не проходили курси 3 педагогіки, але й досвідченим фахівцям вищої медичної школи. Особливо важливим є вибір теми конференції, вона відповідас тим проблемам, які бачать викладачі сьогодні й саме в цьому вузі, й саме зараз пробують їх долати.

The artecle adduces the experience of State Establishment "Luhansk State Medical University" in holding annual practical and pedagogical conferences. The conclusion is made that holding of such conferences presents a system of obtaining skills in different concerns of medical education by all the lecturers of the university and it is the element of pedagogical technology, that enables to improve pedagogical skills not only of young lecturers who have not taken their pedagogical course, but experienced teachers of high medical school as well. The choice of the topic is rather important as it corresponds the current problems seen by the lecturers of the particular educational establishment and they need to overcome them without delay.
\end{abstract}

Вступ. У сучасному суспільстві освіта - складне й багатоманітне соціальне явище, сфера передавання, засвоєння й перероблення знань і соціального досвіду. Педагогічна діяльність у суспільній ієрархії професій за складністю та відповідальністю виконуваної роботи належить до найбільш значущих. Ї̈ї престиж залежить не стільки від матеріально-грошового еквіваленту, скільки від соціальної культури, яка нагороджує й стверджує істинний сенс людського буття [1]. При цьому вища педагогічна освіта виконує особливу, ключову функцію у формуванні сучасної людини, іiі інтелектуального та духовного потенціалу. Стратегія розвитку сучасного українського суспільства в умовах соціально-економічних реформ об' єктивно потребує підвищення вимог до освітньої системи та професійної підготовки фахівців високої кваліфікації [2]. Сьогодні бути педагогічно досвідченим фахівцем неможливо без оволодіння інноваційними освітніми технологіями. Останнім часом поняття “педагогічна технологія" дедалі більше поширюється в науці й освіті. Його варіанти "педагогічна технологія”, “технологія навчання”, “освітні техно- логії”, “технології в навчанні”, “технології в освіті” широко використовуються в психолого-педагогічній палітрі і мають багато формулювань, залежно від того, як автори уявляють структуру і компоненти освітнього процесу [3]. На сьогодні викладачі вищих навчальних медичних закладів свою педагогічну майстерність удосконалюють на курсах підвищення кваліфікації провідних медичних ВНЗ України. Але, як показує багаторічний досвід, цього недостатньо. Тому вже багато років в ДЗ “Луганський державний медичний університет” щорічно проводяться навчально-методичні конференції. Досвідом про організацію цих конференцій ми вважаємо доцільним поділитися із колегами з інших медичних університетів.

Основна частина. Організація щорічних навчально-методичних конференцій має давню історію. Ще за радянських часів, в період зимових студентських канікул почали проводити такі конференції. Але на цих конференціях вирішувались не тільки педагогічні проблеми колективу, а й політично-комуністичні, та громадської оборони, інші організаційні питання. 3 роками, особливо останні 10 років ці навчально-ме-

() В. К. Івченко, В. В. Сімрок 
тодичні конференції присвячені проблемам педагогічної майстерності, удосконаленню навчального процесу, питанням підвищення якості медичної освіти. Вони, як і раніше, проводяться під час зимових студентських канікул. Час проведення обумовлений можливістю участі всіх викладачів, без винятку, взяти участь у конференції. Тематику майбутньої конференції проректор обговорює з деканами факультетів та головами методичних циклових комісій. Залежно від тих проблем, які найбільш важливі на даний період, й формуються тема та регламент конференції. Ми наведемо лише декілька тематик, за якими ми проводили конференції. Так, у 2010 році тема конференції була такою: “Методологія підготовки до практично-орієнтованого державного іспиту з урахуванням типових завдань діяльності, вмінь та навичок відповідно до ОКХ і ОПП за напрямами "Медицина" та "Фармація". Незважаючи на те, що існує низка законодавчих документів, що регламентують державні іспити, співробітниками університету були обговорені питання складання іспиту біля ліжка хворого, особливо з урахуванням розкладу роботи клінічних відділень, пологового будинку, дитячих стаціонарів, на базі яких проходять іспити. Досвідом ділились провідні фахівці університету, висвітлили досягнення, переваги, вказали на недоліки. В 2011 році, враховуючі значні темпи технічної оснащеності університету, розширення комп'ютерної бази, тема конференції була: "Застосування новітніх технологій у навчальному процесі”. Ця тематика була корисною для тих, хто виріс на цих технологіях, а також й тим викладачам, хто тільки почав їх засвоювати. Про якість знань йдеться на всіх освітянських конференціях, на робочих нарадах та в установчих документах. Тому в

\section{Література}

1. Професійна культура викладача вищої школи. Філософсько-педагогічні аспекти формування свідомості технічної інтелігенції : матеріали Всеукраїнської науково-практичної конференції (10 березня 2011 р.). - Красноармійськ : КІІ ДонНТУ, 2011. -403 c.

2. Вітвицька С. С. Основи педагогіки вищої школи : [підручник за модульно-рейтинговою системою навчан-
2012 році ми провели конференцію “Контрольні заходи оцінки якості засвоєння знань. Загальні підходи. Шляхи удосконалення". Така конференція була необхідною у зв'язку із повним переходом на кредитно-модульну систему навчання на всіх факультетах. Поділитися накопиченим досвідом та удосконалити поточні заходи забажали викладачі як теоретичних, так і клінічних кафедр. Але найцікавішою, на наш погляд, стала конференція у 2013 поточному році: "Проблема формування світогляду майбутніх спеціалістів: від історії медицини до роботи біля ліжка хворого та в операційній”. Було розглянуто багато цікавих й корисних питань: світогляд як система найзагальніших знань, цінностей та переконань; науково-обгрунтована медична практика студентів - як складова формування світогляду майбутнього лікаря та провізора; формування у майбутнього лікаря якісно нового підходу в медицині: лікар загальної практики сімейний лікар - гарант своєчасної діагностики та лікування пацієнта, а також багато інших доповідей. Кожна конференція завершується прийняттям резолюції, в обговоренні якої беруть участь всі викладачі університету, та яка відповідає дійсності.

Висновок. На наш погляд, проведення таких конференцій являє собою систему набуття педагогічної майстерності з різних питань медичної освіти всіма викладачами університету, є елементом педагогічної технології, що дозволяє підвищити педагогічну майстерність не тільки молодих викладачів, які ще не проходили курси з педагогіки, але й досвідченим фахівцям вищої медичної школи. Особливо важливим $€$ вибір теми конференції, вона відповідає тим проблемам, які бачать викладачі сьогодні й саме в цьому вузі, й саме зараз пробують їх долати.

ня для студентів магістратури] / С. С. Вітвицька. - Київ : Центр навчальної літератури, 2006.-384 с.

3. Пономаренко О. В. Сучасні інноваційні педагогічні технології організації навчально-виховного процесу вищої школи / О. В. Пономаренко // Вісник Запорізького національного університету. - 2011. - № 2(15). - С. 149-153. 